\title{
Microbiological, Chemical and Sensory Properties of Domestic Donkey'S Milk from Autochthones Serbian Breed
}

\author{
Jasmina M. Gubić, Ljubiša Ć. Šarić*, Bojana M. Šarić, Anamarija I. Mandić, Pavle T. Jovanov, \\ Dragana V. Plavšić, Đorđe G. Okanović \\ University of Novi Sad, Institute of Food Technology, 21000 Novi Sad, Bulevar cara Lazara 1, Serbia \\ *Corresponding author: ljubisa.saric@fins.uns.ac.rs
}

Received August 02, 2014; Revised August 26, 2014; Accepted September 12, 2014

\begin{abstract}
The aim of this study was to investigate microbiological, chemical and sensory properties of raw donkeys' milk from an autochthonous breed originated from Serbia. Changes in microbiota during the six days of storage at $4^{\circ} \mathrm{C}$ were monitored by enumeration of total count of bacteria, yeasts and moulds, coagulase positive staphylococci, lactic acid bacteria, bacterial endospores, Escherichia coli, Clostridium perfringens and Salmonella spp. Descriptive method was used for determination of sensory properties. Descriptive terms were developed to describe appearance (colour), flavour, taste and aftertaste. Chemical analyses included determination of protein, milk fat, dry matter, lactose and vitamin C content. After five days of storage at $4^{\circ} \mathrm{C}$ microbiological quality of the raw Domestic Balkan donkeys' milk was in accordance with the requirements of European Regulation. The obtained results indicate strong antimicrobial activity of the tested milk and longer shelf-life in comparison to other raw milk sources. Sensory properties of the tested raw milk were acceptable within four days of storage at $4^{\circ} \mathrm{C}$. High vitamin C content $(32.95 \mu \mathrm{g} / \mathrm{mL})$, low protein $(1.67 \%$, w/w) and milk fat $(0.66 \%$, w/w) content make the tested milk as valuable potential component of functional food.
\end{abstract}

Keywords: donkeys' milk, microbiological properties, sensory properties, chemical composition

Cite This Article: Jasmina M. Gubić, Ljubiša Ć. Šarić, Bojana M. Šarić, Anamarija I. Mandić, Pavle T. Jovanov, Dragana V. Plavšić, and Đorđe G. Okanović, "Microbiological, Chemical and Sensory Properties of Domestic Donkey'S Milk from Autochthones Serbian Breed.” Journal of Food and Nutrition Research, vol. 2, no. 9 (2014): 633-637. doi: 10.12691/jfnr-2-9-17.

\section{Introduction}

The therapeutic effects of donkeys' milk have been known since ancient times, while nowadays the research is addressed towards its nutrient composition and health effects. Donkeys' milk has lower content of fat, protein and inorganic salts, and higher content of lactose in comparison to bovine milk. Low casein content, high percentage of essential amino acids, protein and lipid profiles similar to those of human milk [13,45,57] favour donkeys' milk as a potential new dietetic food and a good alternative for infant nutrition in the case of cow's milk protein allergy (CMPA) [20,35,58]. Several studies reported potential anti-inflammatory effect $[12,27]$ and positive effect of donkeys' milk on the prevention of atherosclerosis [54]. Anti-proliferative and anti-tumor effect of some active compounds in donkeys' milk on human lung cancer cells have also been reported [30]. High concentration of polyunsaturated fatty acids, vitamins $\mathrm{A}, \mathrm{B}, \mathrm{C}$ and low cholesterol level contribute to donkeys' milk functionality [48].

The Domestic Balkan donkey is an autochthonous breed primarily farmed in the Northern and Eastern regions of Serbia [16,28]. In the past, the population of Domestic Balkan donkeys was widespread throughout the mountain region of Serbia and other countries of the Western Balkan. Nowadays, this population is endangered and in Serbia it is estimated at about 1000 by the FAO DAD-IS [16]. Donkey' milk has been traditionally used in Serbia as a natural remedy for treatment of many diseases including asthma and bronchitis. Since estimated deaths by respiratory diseases in Serbia is higher than Europe and world average [11], there has been a growing demand for donkeys' milk on the Serbian market, recently. Despite that fact, chemical properties of the Domestic Balkan donkeys' milk and its potential for use as functional food has never been investigated. Local consumers in Serbia usually consumed raw donkeys' milk cooled at $4{ }^{\circ} \mathrm{C}$ and refrigerated for a few days. The examination of microbiological profile of this milk during prolonged refrigeration can answer the question if the unpasteurized donkeys' milk can pose a serious health risk for consumers.

The aim of this study was to investigate the chemical and sensory properties of Domestic Balkan donkeys' milk, as well as changes in microbiota during the six days of storage at $4^{\circ} \mathrm{C}$. 


\section{Material and Methods}

\subsection{Sample Collection}

Donkeys' milk samples were collected immediately after morning milking from "Zasavica" Special Nature Reserve. The milk obtained from eight manually milked donkeys was collected, shaken and kept in an ice box at $4^{\circ} \mathrm{C}$ during the transport. The milk sample was divided into three equal parts designated to study its microbiological, chemical and sensory properties. The milk sample assigned to microbiological examination was further divided into seven subsamples of $50 \mathrm{~mL}$ each, intended to study the changes in microbial composition during six days of storage. One sub-sample was examined immediately, while the others were stored at $4^{\circ} \mathrm{C}$ and analysed on a daily basis. Donkeys' milk samples were collected three times following the same sampling procedure.

\subsection{Determination of Changes in Microbial Composition during the Storage}

Changes in microbiota during the six days of storage at $4^{\circ} \mathrm{C}$ were monitored by enumeration of betaglucuronidase-positive Escherichia coli, yeasts and moulds, total count of bacteria, coagulase positive staphylococci, and Clostridium perfringens, according to ISO methods [21,22,23,25,26]. Enumeration of bacterial endospores was performed by incubation of previously heated $\left(100^{\circ} \mathrm{C}, 5 \mathrm{~min}\right)$ milk samples on nutrient agar (Himedia, India) at $30^{\circ} \mathrm{C}$ for $72 \mathrm{~h}$ according to Serbian legislation [43]. The lactic acid bacteria count was determined by incubation $\left(30^{\circ} \mathrm{C}, 72 \mathrm{~h}\right)$ of inoculated Man, Rogosa and Sharpe (MRS) agar (LabM, United Kingdom). Coliform bacteria and Enterobacteriaceae were determined according to AOAC methods [2,3]. Detection of Salmonella spp. was carried out according to the ISO method [24]. All experiments were performed in triplicate.

\subsection{Sensory Analysis}

Donkeys' milk samples were tempered on $15^{\circ} \mathrm{C}$ before analysis to allow the release of odors and flavors [4]. Approximately $25 \mathrm{~mL}$ of each sample was given to the assessors in 3-digits coded covered glasses. Sensory evaluation was performed during 6 days in order to test milk stability. Descriptive sensory analysis was performed by a trained eight-member panel. The panelists were selected according to SRPS ISO method [51]. Sensory evaluation was carried out in individual boxing in the laboratory according to SRPS ISO method [52]. Descriptive terms were developed for the assessment of sensory quality and intensity of colour, flavour, taste and aftertaste using terms from the lexicon of SRPS ISO method [50]. The panelists used attributes, definitions and references from previous sensory studies of milk [4]. The following data scale was used: 1-typical, optimal quality; 2-neither good nor poor quality; 3-poor quality.

\subsection{Chemical Analysis}

Protein, milk fat, lactose content and dry matter were determined by the IDF standards [6]. The vitamin C content was determined by enzymatic method [33].

\section{Results and Discussion}

The changes of microbiota of donkeys' milk during six days of storage at $4^{\circ} \mathrm{C}$ are presented in the Figure 1 .

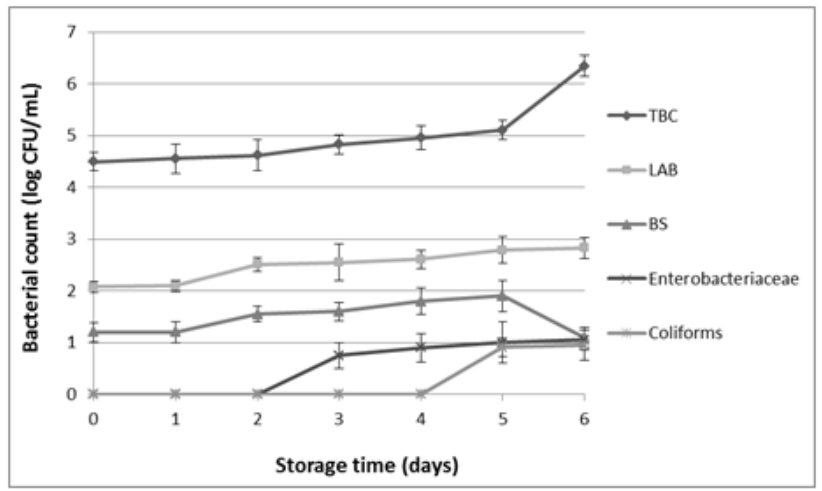

Figure 1. Total bacteria count (TBC), lactic acid bacteria (LAB), bacterial endospores (BS) Enterobacteriaceae and coliforms counts in raw donkeys' milk during six days of storage at $4{ }^{\circ} \mathrm{C}$ (mean values of three independent experiments)

The results of three independent experiments indicate that there was no significant difference $(P<0.05)$ between total bacterial counts at the beginning $(4.24 \pm 0.90-4.79$ $\pm 0.55) \log \mathrm{CFU} / \mathrm{mL}$ and after five days of storage (4.89 \pm $0.16-5.22 \pm 0.76) \log \mathrm{CFU} / \mathrm{mL}$, whereas increase was observed on $6^{\text {th }}$ day $(6.17 \pm 0.40-6.57 \pm 0.90) \log$ $\mathrm{CFU} / \mathrm{mL}$. From the initial number of $(2.08 \pm 0.03-2.10 \pm$ 0.90) $\log \mathrm{CFU} / \mathrm{mL}$ lactic acid bacteria count slightly increased to $(2.60 \pm 0.31-2.95 \pm 0.05) \log \mathrm{CFU} / \mathrm{mL}$ after six days. Bacterial endospores remained at low level $(<2$ $\log \mathrm{CFU} / \mathrm{mL}$ ) during the storage period. In the first experiment, Enterobacteriaceae and coliforms were not detected until the $2^{\text {nd }}$ and $4^{\text {th }}$ day, respectively, whereas in the other two trials these bacteria were not detected during all six days of storage. The presence of Salmonella spp., E. coli, C. perfringens, coagulase positive staphylococci, yeasts and moulds were not observed in any of the analysed samples. The obtained results were in accordance with findings of other authors who also reported low total bacterial count $[10,45,47,49,59]$ as well as low count of lactic acid bacteria $[8,10]$ in raw donkeys' milk. Total bacterial count in raw milk of conventional dairy species (bovine, goat and sheep) is generally higher and depends on hygienic practice during milking and further milk manipulation. According to literature data total bacterial count in these types of milk can reach the values higher than 7 or $8 \log \mathrm{CFU} / \mathrm{mL}$ $[7,36,40,42]$. Comparing the results of lactic acid bacteria count in bovine and donkeys' milk it was found significantly higher amount of these bacteria in bovine milk (3.4 - 6.8 log CFU/mL) [18]. In raw milk from other sources pathogenic bacteria were found more frequently and in higher count compared to raw donkeys' milk. On example, Salmonella spp. has never been detected in raw donkeys' milk $[1,9,47,59]$, while $3-6 \%$ of samples of raw bovine milk were positive on Salmonella spp. with an average number of $2.3 \log \mathrm{CFU} / \mathrm{mL}$ [42]. Low microbial count determined during 5 days of storage as well as absence of pathogenic microorganisms could be explained by the high concentration of lysozyme ( $1-4 \mathrm{~g} / \mathrm{L})$ in donkeys' milk $[8,10,57]$. Unlike the donkeys' milk, 
bovine milk have a minor content of lysozyme (0.05 $0.21 \mathrm{mg} / \mathrm{L}$ ) $[5,15]$, while the level of this enzyme in goat and owine milk is apromaxitely 0.25 and $0.1 \mathrm{mg} / \mathrm{L}$, respectively $[5,41]$. Except lysozyme this type of milk possesses many other antimicrobial agents including lactoferrin [59]. Despite the fact that low count of autochthonous lactic acid bacteria was observed in this study, their supporting role in the total antimicrobial activity of donkeys' milk should not be excluded. According to the previous reports different compounds (including bacteriocins) produced by lactic acid bacteria possessed strong antimicrobial activity [53]. Therefore it would be useful to investigate the biodiversity of autochthonous lactic acid bacteria present in Domestic Balkan donkeys' milk and their ability to produce antimicrobial compounds. Strong antimicrobial activity of donkeys' milk has been previously reported [46,55,59].

Sensory properties of the tested milk are shown in the Figure 2. Typical milk colour did not change during all six days of assessment. Aroma was poorly expressed during the first three days, whereas on $4^{\text {th }}$ day a milky-sweet flavour appeared and became more intense during the next two days leading to a lack of freshness.

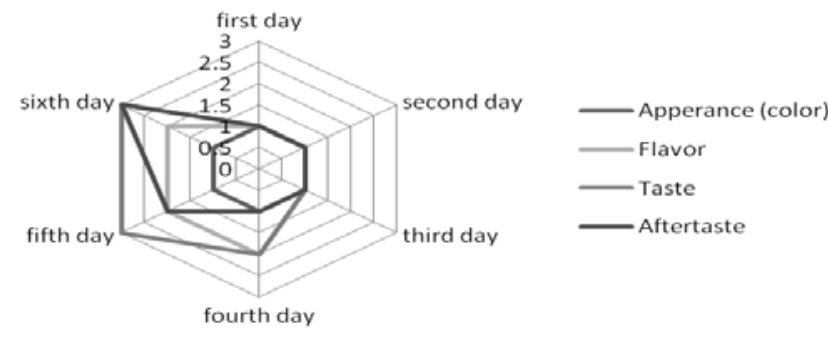

Figure 2. Changes in the sensory properties of raw donkeys' milk during six days of storage at $4^{\circ} \mathrm{C}$

Panel members defined milk taste as a pleasant, with a slight sweetness originating from lactose. In terms of overall acceptability of taste, panellists did not observe any changes during the first three days of experiment. However, slightly bitter taste appeared on $4^{\text {th }}$ day and intensified during the next days. For this reason, on $5^{\text {th }}$ day milk was assessed as non specific according to its primary and residual bitter taste. The obtained results indicate that raw Domestic Balkan donkeys' milk was sensory acceptable during four days of storage at $4^{\circ} \mathrm{C}$. This was in accordance with its microbiological quality.

Results of the chemical composition of raw donkeys' milk are summarized in Table 1. Determined total solids, protein, milk fat and lactose content of the tested milk were in the range of previously reported amounts in milk of other donkey breeds [19,39,45].

Table 1. Chemical composition of raw donkeys' milk

\begin{tabular}{cc}
\hline Chemical characteristics & (mean \pm standard deviation) \\
\hline Total solids $(\%, \mathrm{w} / \mathrm{w})$ & $8.58 \pm 0.32$ \\
Protein content $(\%, \mathrm{w} / \mathrm{w})$ & $1.67 \pm 0.20$ \\
Milk fat content $(\%, \mathrm{w} / \mathrm{w})$ & $0.66 \pm 0.11$ \\
Lactose content $(\%, \mathrm{w} / \mathrm{w})$ & $7.07 \pm 0.14$ \\
Vitamin $\mathrm{C}(\mu \mathrm{g} / \mathrm{mL})$ & $32.95 \pm 1.38$ \\
\hline
\end{tabular}

Protein, lactose, fat and mineral content of donkeys' milk, as well as that of mare's milk, is more similar to human milk than to bovine milk $[37,45]$. Generally, donkeys' milk has low total solids (8\% - 10\%) and protein content $(1.25 \%-2.18 \%)$ as well as high lactose content (6.01\%-7.28\%), while fat content ranges between $0.10 \%$ and $1.82 \%$ [19,39,45]. The reported variations in chemical composition can be due to the effect of lactation stage. Except the lactation stage chemical composition of milk could be affected by breed, breeding area and forage, milking technique, and interval between milking, which was previously reported [17]. Average values of fat content of donkeys' milk ranged from $0.45 \%$ at the beginning to $1.49 \%$ at the end of lactation [19]. The protein content was also affected by stage of lactation, which was observed in Haflinger mare's milk [31] and bovine milk [17]. The high lactose content was generally observed at early and late stages of lactation. The level of lactose in donkeys' milk is quite similar to that in human milk (6.30-7.00\%) while in bovine and other ruminant milk lactose content is 1.5 times higher [56]. Lactose gives good taste to donkeys' milk [35] and it is essential for the development of the nervous system. Based on protein and lactose content similar to human milk, donkey milk could be better alternative for human milk compared to bovine milk [29]. The good digestibility and the lower renal solute load also confirm donkeys' milk as suitable for infant nutrition $[56,60]$. The reported total vitamin C content detected in donkeys' milk presents recommended daily intake of vitamin $C$ for children aged between 6-12 months [32,34]. These properties of donkeys' milk emphasise its significance as healthy food for humans [38].

In conclusion, microbiological quality of donkeys' milk during the six days of storage at $4^{\circ} \mathrm{C}$ indicate that this milk could be a safe food, if the animals are healthy and milked in proper hygienic conditions. After five days, microbiological quality of the raw Domestic Balkan donkeys' milk was in accordance with the requirements of European Regulation for raw milk from species other than bovine [44], which indicates its longer shelf-life in comparison to other raw milk sources. Sensory properties of the tested raw milk were acceptable within four days of storage at $4^{\circ} \mathrm{C}$. High vitamin $\mathrm{C}$ content, low protein and milk fat content make the tested milk as valuable potential component of functional food.

\section{Acknowledgements}

This work is a part of the National Project (TR-31029) financially supported by the Ministry of Education and Science, Republic of Serbia. Authors are grateful to Slobodan Simić and Nikola Nilić (Special Nature Reserve "Zasavica", Serbia) for providing the milk samples.

\section{References}

[1] Alberghini L, Catellani P, Norbiato M.A, Giaccone V, "Microbial status of donkey's milk: first results”, Ital J Food Saf, 1 (3). 7-10. 2012.

[2] Association of Official Analytical Chemistry (A.O.A.C.). Official method 996.02: Coliform count in dairy products, Washington DC. 2002.

[3] Association of Official Analytical Chemistry (A.O.A.C.). Official method 2003.01: Enumeration of Enterobacteriaceae in Selected Foods, Washington DC. 2003.

[4] Bandler D.K, Barnard S.E, "The Sensory Evaluation of Dairy Products”, Milk Flavor \& Quality. 1984.

[5] Benkerroum N, "Antimicrobial activity of lysozyme with special relevance to milk”, Afr J Biotechnol, 7 (25). 4856-4867. 2008.

[6] Carić M, Milanović S, Vucelja D, "Standardne metode analize mleka i mlečnih proizvoda", Novi Sad. 2000. 
[7] Chambers J.V, "The microbiology of raw milk", In: R. K Robinson (ed.), Dairy Microbiology Handbook: The Microbiology of Milk and Milk Products, (3rd ed). (pp. 39-91). John Wiley and Sons, Inc. New York, USA. 2002.

[8] Chiavari C, Coloretti F, Nanni M, Sorrentino E, Grazia L, (2005). "Use of donkey's miilk for a fermented bevarege with lactobacilli", Lait, 85. 481-490. 2005.

[9] Conte F, Scatassa M.L, Monsu G, Lo Verde V, Finocchiaro A, De Fino M, "Monitoring of safety and quality of donkey's milk", In F. J. M. Smulders \& J. D. Collins (Eds.), Food safety assurance and veterinary public health: Towards a risk-based chain control. (1st ed.). (pp. 265-268). Wageningen Academic Publishers, The Netherlands. 2006.

[10] Coppola R, Salimei E, Succi M, Sorrentino E, Nanni M, Ranieri P, "Behaviour of Lactobacillus rhamnosus strains in ass's milk", Ann Microbiol, 52. 55-60. 2002.

[11] Easthorn Clinical Services in Central and Eastern Europe, Serbia, URL. $\quad$ http://www.easthorn.com/geographicalreach/serbia/Accessed 15.07.2014.

[12] Ellinger S, Linscheid K.P, Jahnecke S, Goerlich R, Endbergs H, "The effect of mare's milk consumption on functional elements of phagocytosis of human neutrophilsgranulocytes from healthy volunteers”, Food Agric Immunol, 14. 191-200. 2002.

[13] Fantuz F, Polidori F, Cheli F, Baldi A, "Plasminogen Activation System in Goat Milk and its Relation with Composition and Coagulation Properties”, J Dairy Sci, 84. 1786-1790. 2001.

[14] Farmers Bulletin 2259, Judging and Scoring Milk and Cheese, Dairy Division, AMS, United States Department of Agriculture, Washington, DC 20250, URL http://www.ams.usda.gov/AMSv1.0/getfile?dDocName=STELDE V3004794 Accessed 15.07.2014.

[15] Floris R, Recio I, Berkhout B, Visser S, "Antibacterial and antiviral effects of milk proteins and derivatives thereof", Curr Pharm Design, 9. 1257-1275. 2003.

[16] Food and Agriculture Organization-Domestic Animal Diversity Information system (FAO DAD-IS). 2009. URL http://dad.fao.org/ Accessed 15.07.2014.

[17] Fox P.F, "The major constituents of milk". Pages 7-19 in Dairy Processing. G. Smit, ed. CRC Press, Washington, DC. 2003.

[18] Franciosi E, Settani L, Cavazza A, Poznanski E, "Biodiversity and technological potential of wild lactic acid bacteria from raw cows' milk”, Int Dairy J, 19. 3-11. 2009.

[19] Guo H.Y, Pang K, Zhang X.Y, Zhao L, Chen S.W, Dong, ML, "Composition, physiochemical properties, nitrogen fraction distribution, and amino acid profile of donkey milk", J Dairy Sci, 90. 1635-1643. 2007.

[20] Iacono G, Carroccio A, Cavataio F, Montalto G, Soresi M, Balsamo V, "Use of ass's milk in multiple food allergy", $J$ Pediatr Gastr Nutr, 14. 177-181. 1992.

[21] ISO 16649-2 (2001). Microbiology of food and animal feeding stuffs-Horizontal method for the enumeration of betaglucuronidase-positive Escherichia coli-Part 2: Colony-count technique at 44 degrees $\mathrm{C}$ using 5-bromo-4-chloro-3-indolyl betaD-glucuronide. Geneva.

[22] ISO 21527-1 (2008). Microbiology of food and animal feeding stuffs-Horizontal method for the enumeration of yeasts and moulds-Part 1: Colony count technique in products with water activity greater than 0.95 , ISO, Geneva.

[23] ISO 4833. Microbiology 304 of food and animal feeding stuffsHorizontal method for the enumeration of microorganismsColony-count technique at 30 degrees C, ISO, Geneva. 2003.

[24] ISO 6579:2002/AC: 2006. Microbiology of food and animal feeding stuffs-Horizontal method for the detection of Salmonella spp, ISO, Geneva. 2006.

[25] ISO 6888-1:1999/A1: 2003. Microbiology of food and animal feeding stuffs-Horizontal method for the enumeration of coagulase-positive staphylococci (Staphylococcus aureus and other species)-Part 1: Technique using Baird-Parker agar medium, ISO, Geneva. 2003.

[26] ISO 7937. Microbiology of food and animal feeding stuffsHorizontal method for the enumeration of Clostridium perfringens-Colony-count technique, ISO, Geneva. 2004.

[27] Jirillo F, Jirillo E, Magrone T, “Donkey's and goat's milk consumption and benefits 311 to human health with special reference to the inflammatory status". Curr Pharm Design, 16. 859-63. 2010.

[28] Kugler W, Grunenfelder H.P, Broxham E, "Donkey Breeds in Europe: Inventory, Description, Need for Action, Conservation”.
In: Report 2007/2008, Monitoring Institute for Rare Breeds and Seeds in Europe, Save foundation, 62. 2008. URL http://www.save-foundation.net/pdf/donkey.pdf Accessed 15.07.2014

[29] Malacarne M, Martuzzi F, Summer A, Mariani P, "Protein and fat composition of mare's milk: some nutritional remarks with reference to human and cow's milk“, Int Dairy J, 12. 869-897. 2002.

[30] Mao X, Gu J, Sun Y, Xu S, Zhang X, Yang H, Ren F, “Antiproliferative and anti-tumour effect of active components in donkey milk on A549 human lung cancer cells”. Int Dairy J, 19. 703-708. 2009.

[31] Mariani P.L, Summer A, Martuzzi F, Formaggioni P, Sabbioni A., Catalano A.L, "Physicochemical properties, gross composition, energy value and nitrogen fractions of Halflinger nursing mare milk throughout 6 lactation months”. Anim Res, 50. 415-425. 2001.

[32] Mariani P.L, "Donkey milk nutraceutical characteristics: a biochemical evaluation of nutritious and clinical properties". Doctorate thesis, University of Camerino. 2008. URL http://cameprints.unicam.it/284/1/Donkey_milk.pdf Accessed 15.07.2014.

[33] Megazyme International Ireland (2011). Megazyme ascorbic acid assay kit K-ASCO 02/11.

[34] Milonis E, Polidori P, "Latte di assina produzione caratteristiche e gestione dell'azienda asinine”, Fondazione iniziative zooprofilattiche e zootecniche-Brescia. 2011.

[35] Monti G, Bertino E, Muratore M.C, Coscia A, Cresi F, Silvestro L, Fabris C, Fortunato D, Giuffrida M.G, Conti A, (2007). "Efficacy of donkey's milk in treating highly problematic cow's milk allergic children: an in vivo and in vitro study”. Pediatr Allergy Iтmu, 18. 258-64. 2007.

[36] Muehlherr J.E, Zweifel C, Corti S, Blanco J.E, Stephan R, "Microbiological quality of raw goat's milk and ewe's bulk-tank milk in Switzerland”, J Dairy Sci, 86 (12). 3849-3856. 2003.

[37] Nazzaro F, Orlando P, Fratianni F, Coppola R, "Isolation of Components with Antimicrobial Property from the Donkey Milk: A Preliminary Study”. The Open Food Science Journal, 4. 43-47. 2010.

[38] Nikkhah A, "Equidae, Camel, and Yak Milks as Functional Foods: A Review “, Journal of Nutrition \& Food, 1-7. 2011.

[39] Oftedal O.T, Jenness R, "Interspecies variation in milk composition among horses, zebras and asses (Perissodactyla: Equidate)". J Dairy Res, 55. 57-66. 1988.

[40] Oliveira C.J.B, Hisrich E.R, Moura J.F.P, Givisiez P.E.N, Costa R.G, Gebreyes W.A, "On farm risk factors associated with goat milk quality in Northeast Brazil”, Small Ruminant Res, 98. 64-69. 2011.

[41] Park Y.W, "Minor species milk", In Y. W. Park \& G. F. W. Haenlein (Eds.), Handbook of Milk of Non-Bovine Mammals (1th. ed.). (pp. 399-400). Blackwell Publishing. 2006.

[42] Poppe C, "Diseases of Dairy Animals-Infectious Diseases: Salmonellosis”, In: J. W. Fuquay, P. F. Fox \& P. H. L. Sweeney (Eds.), Encyclopedia of Dairy Sciences, (2nd ed.). Academic Press. 2011.

[43] Regulation on methods of microbiological analysis and super analysis of food. Sl.list, SFRJ, No 25/80, 9.5.1980, 857. 1980.

[44] Regulation no 853/2004 of the European Parliament and of the council of 29 April 2004 laying down specific hygiene rules for food of animal origin. Official Journal of the European Union, L 139, 22-82. 2004.

[45] Salimei E, Fantuz F, Coppola R, Chiofalo B, Polidori P, Varisco G, "Composition and characteristics of ass's milk". Anim Res, 53. 6778. 2004.

[46] Šarić Ć.Lj, Šarić M.B, Kravić S.Ž, Plavšić D.V, Milovanović I.Lj, Gubić J.M, Nedeljković N.M, "Antibacterial activity of Domestic Balkan donkey milk toward Listeria monocytogenes and Staphylococcus aureus." Food and Feed Research, 41 (1). 47-54. 2014.

[47] Sarno E, Santoro A.M.L, Di Palo R, Costanzo N, "Microbiological quality of raw donkey milk from Campania Region”, Ital J Anim Sci, 11 (49). 266-269. 2012.

[48] Solaroli G, Pagliarini E, Peri C, "Composition and nutritional quality of mare's milk”. Ital J Food Sci, 1. 3-10. 1993.

[49] Sorrentino E, Di Renzo T, Succi M, Reale A, Tremonte P, Coppola R, Salimei E, Colavita G, "Microbiological characteristics of raw ass's milk: manual vs. machine milking", Book of Abstracts of the 61st Annual Meeting of the European 
Association for Animal Production. pp. 44. Wageningen Academic Publishers. 2010.

[50] SRPS ISO 5492, Sensory analysis-Vocabulary. 2000.

[51] SRPS ISO 8586-1, Sensory analysis-General quidance for the selection, training and monitoring of assessors. 2002

[52] SRPS ISO 8589, Sensory analysis-General quidance for the desing of test rooms. 1998.

[53] Šušković J, Kos B, Beganović J, Pavunc A.L, Habjanič K, Matošić $\mathrm{S}$, "Antimicrobial activity-The most important property of probiotic and starter lactic acid bacteria", Food Technol Biotechnol, 48 (3). 296-307. 2010.

[54] Tafaro A, Magrone T, Jirillo F, Martemucci G, D’Alessandro A, Amati L, Jirillo E, (2007). Immunological properties of donkey's milk. Its potential use in the prevention of atherosclerosis. Curr Pharm Design, 13. 3711-3717. 2007.

[55] Tidona F, Sekse C, Criscione A, Jacobsen M, Bordonaro S, Marletta D, Vegarud G.E, “Antimicrobial effect of donkeys’ milk digested in vitro with human gastrointestinal enzymes”. Int Dairy J, 21. 158-165. 2011.

[56] Uniacke-Lowe T, "Studies on equine milk and comparative studies on equine and bovine milk systems". PhD Thesis, University College Cork. 2011.

[57] Vincenzetti S, Polidori P, Mariani P, Cammertoni N, Fantuz F, Vita A, "Donkey's milk protein fractions characterization". Food Chem, 106. 640-649. 2008.

[58] Vita D, Passalacqua G, Di Pasquale G, Caminiti L, Crisafulli G, Rulli I, Pajno G.B, "Ass's milk in children with atopic dermatitis and cow's milk allergy: crossover comparison with goat's milk". Pediatr Allergy Immu, 18. 594. 2007.

[59] Zhang X.Y, Zhao L, Jiang L, Dong M.L, Ren F.Z, "The antimicrobial activity of donkey milk and its microflora changes during storage”. Food Control, 19. 1191-1195. 2008.

[60] Ziegler E, “Adverse effects of cow's milk in infants issues in complementary feeding“, Nestec Ltd., Vevey/S. Karger AG, Basel, Nestlé Nutr Workshop Ser Pediatr Program, vol. 60, pp. 